\title{
Glucose supplementation has minimal effects on blood neutrophil function and gene expression in vitro
}

\author{
M. Garcia, ${ }^{*}$ T. H. Elsasser,† Y. Qu, ${ }^{*}$ X. Zhu,‡ and K. M. Moyes ${ }^{* 1}$ \\ *Department of Animal and Avian Sciences, University of Maryland, College Park 20740 \\ †USDA, Agricultural Research Service, Animal Biosciences and Biotechnology Laboratory, Beltsville, MD 20705 \\ łLaboratory of Immunology, Virginia-Maryland Regional College of Veterinary Medicine, University of Maryland, College Park 20740
}

\section{ABSTRACT}

During early lactation, glucose availability is low and the effect of glucose supply on bovine polymorphonuclear leukocyte (PMNL) function is poorly understood. The objective of this study was to determine the effect of glucose supplementation on the function and transcriptomic inflammatory response of PMNL from cows in early and mid-lactation in vitro. Twenty Holstein cows in early $(\mathrm{n}=10$; days in milk $=17 \pm 3.1)$ and mid-lactation $(\mathrm{n}=10$; days in milk $=168 \pm 14.8)$ were used for this study. Jugular blood was analyzed for serum concentrations of nonesterified fatty acids, $\beta$-hydroxybutyrate, and glucose. Polymorphonuclear leukocytes were isolated and diluted using RPMI (basal glucose concentration was $7.2 \mathrm{mM}$ ) to different concentrations of $\mathrm{PMNL} / \mathrm{mL}$ for phagocytosis, chemotaxis, gene expression, and medium analyses. Working solutions of glucose (0 or $4 \mathrm{mM}$ of D-glucose) and lipopolysaccharide $(0$ or $50 \mu \mathrm{g} / \mathrm{mL})$ were added and tubes were incubated for $120 \mathrm{~min}$ at $37^{\circ} \mathrm{C}$. Media were analyzed for concentrations of glucose and tumor necrosis factor- $\alpha$ $(\mathrm{TNF}-\alpha)$. Data were analyzed in a randomized block (stage of lactation) design. Challenge with lipopolysaccharide increased the expression of the genes encoding for nuclear factor kappa B (NFKB1), IL-10 (IL10), IL1B, IL6, IL8, TNF- $\alpha$ (TNFA), glucose transporter 3 (SLC2A3), and the concentration of TNF- $\alpha$ in medium (147.3 vs. $72.5 \mathrm{pg} / \mathrm{mL}$ for lipopolysaccharide and control, respectively). Main effect of stage of lactation was minimal where the expression of IL10 increased for cows in early compared with cows in mid-lactation. After lipopolysaccharide challenge, cows in early lactation experienced more marked increases in the expression of IL6, TNFA, and IL8 when compared with cows in midlactation. Glucose supplementation had minimal effects on gene expression where glucose supplementation

\footnotetext{
Received December 2, 2014

Accepted May 5, 2015.

${ }^{1}$ Corresponding author: kmoyes@umd.edu
}

increased the expression of lysozyme ( $L Y Z)$. Glucose supplementation increased PMNL phagocytosis but did not alter chemotaxis, morphology, or concentration of TNF- $\alpha$ in the medium. Under the conditions of the experiment, stage of lactation had minimal effects on PMNL response to glucose supply where only the expression of NFKB1 and the production of TNF- $\alpha$ were greater for cows in mid-lactation when compared with early lactation. Metabolic profiles for cows in early lactation did not parallel those for cows during the early postpartum period and may partly explain results for this study. Future studies investigating the effect of glucose supply on bovine PMNL function in vivo and how this may be altered by stage of lactation are warranted. Key words: glucose, inflammation, lactating cow, neutrophil

\section{INTRODUCTION}

Inflammation of the mammary gland (i.e., mastitis) is usually associated with the presence of a pathogen from either gram-positive or gram-negative bacteria (Kehrli and Shuster, 1994). During mastitis, circulating PMNL are of key importance in controlling the severity and duration of mastitis, accounting for approximately $95 \%$ of somatic cell population in milk (Kehrli and Shuster, 1994; Burvenich et al., 2007). Most periparturient cows mobilize body tissue to meet the nutrient demands for lactation and hence experience some degree of negative energy balance, characterized by changes in circulating NEFA, BHBA, and glucose (Drackley et al., 2006). The metabolites associated with degree of negative energy balance, such as circulating BHBA and NEFA, can impair several aspects of the immune response (Ingvartsen and Moyes, 2013). Coupled with natural immunosuppression, as well as changes in the hormonal, neurological, and digestive systems, cows are at high risk of development of diseases, especially mastitis, during early lactation (Ingvartsen, 2006).

Studies in humans and rodent models have revealed that glucose is the preferred fuel for phagocytic cells 
such as macrophages and PMNL (Newsholme et al., 1987; Newsholme and Newsholme, 1989; Healy et al., 2002; Pithon-Curi et al., 2004). Indeed, activated phagocytic cells supplemented with glucose showed enhancement of metabolism by increasing the production of lactate, ATP, and activity of enzymes involved in glycolysis, the pentose phosphate pathway, and the citric acid cycle (Newsholme and Newsholme, 1989; Spolarics et al., 1991; Healy et al., 2002; Pithon-Curi et al., 2004). In addition, glucose supplementation enhanced phagocytosis and the production of reactive oxygen species in phagocytic cells (Barghouthi et al., 1995; Furukawa et al., 2000). During the inflammatory response, research has shown that systemic metabolic changes occur including increased circulating glucose concentrations in lactating dairy cows (Moyes et al., 2014) and nonlactating heifers (Steiger et al., 1999). Hence, glucose may be spared for utilization by phagocytic cells, such as PMNL, rather than the synthesis of milk components in the mammary gland as proposed by Gross et al. (2014). During early lactation, glucose availability is low and may partly explain the natural immunosuppression observed at this time. The hypothesis of the present study was that additional glucose will improve the metabolic and inflammatory response of bovine blood PMNL after LPS challenge and that supplemental glucose will improve PMNL response for cows in early lactation when compared with cows in mid-lactation. The objective of this study was to determine the effect of glucose supplementation on the inflammatory and metabolic response of PMNL for cows in early and mid-lactation in vitro.

\section{MATERIALS AND METHODS}

All procedures involving the use of live animals were approved in accordance with the regulations and guidelines set forth by the USDA Beltsville Animal Care and Use Committee.

\section{Animals}

Fourteen primiparous and 7 multiparous $(\geq 2$ lactations) Holstein cows in early $(\mathrm{n}=10 ; \mathrm{DIM}=17 \pm 3.1$; $34.2 \mathrm{~kg}$ of milk/d) and mid-lactation $(\mathrm{n}=10 ; \mathrm{DIM}=$ $168 \pm 14.8 ; 37.8 \mathrm{~kg}$ of milk/d) were used for this study. All cows were free from clinical signs of disease before sample collection for this study with median composite milk SCC of 107,000 cells/mL. All cows were housed and fed in free stalls, had free access to water, and were milked twice daily at 0600 and $1800 \mathrm{~h}$. At 0730, 1400, and $1730 \mathrm{~h}$, cows were fed ad libitum daily a TMR formulated to provide the NRC (2001) requirements
$\left(\mathrm{NE}_{\mathrm{L}}=1.65 \mathrm{Mcal} / \mathrm{kg}\right.$ of $\mathrm{DM}, \mathrm{CP}=17.2 \%$ of DM $)$ of lactating dairy cows averaging 100 DIM and producing $40 \mathrm{~kg}$ of milk/d with BW and BCS of $610 \mathrm{~kg}$ and 2.5, respectively.

Jugular blood $(\sim 150 \mathrm{~mL})$ was collected from each cow after the morning milking and before the morning feeding. Blood was collected into vacutainer tubes containing acid-citrate dextrose (Fisherbrand, Thermo Fisher Scientific Inc., Pittsburgh, PA), inverted to mix and placed on ice. Blood samples were processed within $1 \mathrm{~h}$ after collection. In addition, blood $(\sim 10 \mathrm{~mL})$ was collected without anticoagulant (Fisherbrand, Thermo Fisher Scientific Inc.). Blood containing no anticoagulant was allowed to clot at room temperature for $\sim 2 \mathrm{~h}$. Tubes were centrifuged at 2,000 $\times g$ for $15 \mathrm{~min}$ at $4^{\circ} \mathrm{C}$ (model 5810R, Eppendorf, Hauppauge, NY) and media were frozen at $-20^{\circ} \mathrm{C}$ for metabolite analysis.

\section{Isolation of PMNL}

Isolation of polymorphonuclear leukocytes, viability, and cell differentiation were performed using endotoxin free materials and reagents, according to the procedures described by Garcia et al. (2015). Briefly, after blood centrifugation, plasma and one-third of the red blood cells (RBC) were discarded and the remaining RBCs were lysed with ice-cold water and isotonicity was restored using PBS. The pellet was washed 3 times in $10 \mathrm{~mL}$ of PBS and resuspended in $1 \mathrm{~mL}$ of calciumand magnesium-free Hanks' buffered saline solution (CMF-HBSS; Sigma-Aldrich Co., St. Louis, MO). Concentrations of PMNL were measured using a TC20 automated cell counter (Bio-Rad Laboratories Inc., Hercules, CA). The viability of PMNL was determined using the trypan blue (0.1\%, Bio-Rad Laboratories Inc.) exclusion method, resulting in an average viability of 94\%. Cell differentials were determined microscopically on cytospin preparations using a commercially available hematology staining kit (Hema-FastTM 3-Step Hematology Staining Kit; Fisherbrand, Thermo Fisher Scientific Inc.), indicating that $85 \%$ of the cells were PMNL.

\section{PMNL Morphology}

Morphology of isolated blood PMNL ( $\mathrm{n}=8$ /stage of lactation) was performed according the procedure described by Moyes et al. (2009). Briefly, 5 fields per cow were evaluated for PMNL morphology. The PMNL were classified as either mature or immature (banded or juvenile) as described by Paape et al. (2003). The percentage of mature PMNL was calculated from the average of the 5 fields per cow and subjected to statistical analysis. 


\section{PMNL Treatment and Incubation}

Cell suspensions were diluted, according to previous studies (Moyes et al., 2009; Garcia et al., 2015), to desired concentrations of $2 \times 10^{6}$ cells $/ \mathrm{mL}$ (phagocytosis assay; final volume $1.0 \mathrm{~mL}), 3 \times 10^{6}$ cells $/ \mathrm{mL}$ (chemotaxis assay; final volume $1.0 \mathrm{~mL}$ ) or $6 \times 10^{6}$ cells/mL (gene expression and medium analyses; final volume $1.0 \mathrm{~mL}$ ) using RPMI 1640 without glutamine (Sigma-Aldrich Co.) containing 5\% heat-inactivated fetal bovine serum (FBS; Sigma-Aldrich Co.). The basal concentration of glucose of PMNL suspended in RPMI 1640 was $7.2 \mathrm{mM}$. Neutrophils have a short half-life (Paape et al., 2003) and therefore nutrients should be provided to media to improve viability of these cells for in vitro experiments (Graugnard et al., 2012; Ster et al., 2012; Garcia et al., 2015). For all assays, working solutions of either control (CTL; no additional glucose) or additional glucose (GLU; $4 \mathrm{~m} M$ of D-glucose, Sigma-Aldrich Co.) were added to each tube. The supplemented glucose was based on physiological glucose concentrations observed in circulation for lactating dairy cows, $<28$ DIM (Qu et al., 2014). Hence, the final concentration of glucose for each treatment was 7.2 $\mathrm{m} M$ for CTL and $11.2 \mathrm{~m} M$ for GLU. For gene expression and medium analyses, flasks were transferred to a sterile hood and either PBS or LPS $(50 \mu \mathrm{g} / \mathrm{mL}$ of total culture medium, L055, Sigma Aldrich Co.) was added to all tubes assigned for gene expression and medium analyses (Revelo and Waldron, 2012). All tubes were incubated for $120 \mathrm{~min}$ at $37^{\circ} \mathrm{C}, 95 \%$ relative humidity, and $5 \% \mathrm{CO}_{2}$ (Revelo and Waldron, 2012; Garcia et al., 2015). After incubation, $1.0 \mathrm{~mL}$ of cell suspensions were transferred into 2.0-mL RNase-free tubes (Fisherbrand, Thermo Fisher Scientific Inc.) and centrifuged (10,000 $\times g$ at $4^{\circ} \mathrm{C}$ for $2 \mathrm{~min}$ ). The spent media were collected and stored at $-80^{\circ} \mathrm{C}$ for analysis of tumor necrosis factor- $\alpha(\mathbf{T N F}-\alpha)$. For gene expression analysis via quantitative reverse-transcription PCR (qPCR), the cell pellet was washed twice with $1.0 \mathrm{~mL}$ of $1 \times$ PBS and $1.0 \mathrm{~mL}$ of TRIzol Reagent (Invitrogen, Carlsbad, CA) with $1 \mu \mathrm{L}$ of linear acrylamide (Ambion Inc., Austin, TX) was added. Polymorphonuclear leukocytes were homogenized by vigorously pipetting up and down and stored at $-80^{\circ} \mathrm{C}$ until further analysis.

\section{PMNL Chemotaxis}

Chemotaxis assay was performed as described by Moyes et al. (2009) with minor modifications. In triplicate, $30 \mu \mathrm{L}$ of either RPMI medium (nonrandom migration) or human IL-8 (Sigma Aldrich Co., $100 \mathrm{ng} /$ $\mathrm{mL}$, specific migration) was added to the bottom wells of a 48-well chemotaxis chamber (Neuro Probe, Gaith- ersburg, MD). Fifty microliters of cell suspension $(3 \times$ $10^{6} \mathrm{PMNL} / \mathrm{mL}$ ) was added to the top of a preloaded filter (Fisherbrand, Thermo Fisher Scientific Inc.). Plates were incubated for $60 \mathrm{~min}$ at $37^{\circ} \mathrm{C}, 5.0 \% \mathrm{CO}_{2}$, and $95 \%$ relative humidity. Five fields per well were counted using a $100 \times$ magnification to determine the number of PMNL that migrated in response to IL-8 or RPMI. An average of the 5 fields per well was calculated. For statistical analysis, a chemotaxis index was calculated by subtracting the random migration (RPMI) from the migration with IL-8.

\section{PMNL Phagocytosis}

Phagocytosis was performed according to procedures described by Garcia et al. (2015). Briefly, fluorescent beads (Fluoresbrite Yellow-Green Carboxylate 1.75$\mu \mathrm{m}$ Microspheres, PolySciences, Warrington, PA) were precoated with heat-inactivated FBS $(250 \mu \mathrm{L}$ of FBS per $1 \mu \mathrm{L}$ of beads; Sigma-Aldrich Co.) at room temperature for $45 \mathrm{~min}$. To each cell population, $100 \mu \mathrm{L}$ of the FBS-coated beads was added to obtain a 10:1 ratio (beads:PMNL). Samples were run in duplicate and incubated for $2 \mathrm{~h}$ at $37^{\circ} \mathrm{C}, 5 \% \mathrm{CO}_{2}$, and $95 \%$ relative humidity, and then centrifuged for $5 \mathrm{~min}(1,000 \times \mathrm{g}$ at $4^{\circ} \mathrm{C}$ ). The pellets were washed in $1 \mathrm{~mL}$ of CMF-HBSS and fixed with $300 \mu \mathrm{L}$ of $4 \%$ paraformaldehyde (SigmaAldrich Co.). The PMNL population was gated by forward and side scatters (XL Flow Cytometer, Beckman Coulter, Fullerton, CA). Data were collected on 20,000 events per sample in the gate set for bovine PMNL, and percentage fluorescence was used as the quantitative index of PMNL response. Phagocytosis by PMNL was expressed as the total percentage of PMNL engulfing one or more beads.

\section{Analysis of Metabolites and Proteins in Serum and Media}

NEFA and BHBA Assays. Serum was analyzed in triplicate for concentrations of NEFA (NEFA-HR kit, Wako Diagnostics Inc., Richmond, VA). The intraassay $\mathrm{CV}$ was $3.1 \%$. Concentrations of BHBA were determined using a commercial kit (Stanbio Laboratories, Boerne, TX) following the manufacturer protocol for a 96-well plate. The intraassay CV was $2.4 \%$.

Glucose Assay and Glucose Utilization. Serum and spent media were analyzed by a glucose oxidase methodology using a commercial kit (Stanbio Laboratories). Manufacturer protocol was adjusted for microplate reading. Briefly, standards were diluted with distilled $\mathrm{H}_{2} \mathrm{O}$. Three microliters of standards, samples, and control were added to a 96-well plate in duplicate followed by $300 \mu \mathrm{L}$ of reagent at $37^{\circ} \mathrm{C}$. This mixture 
was then incubated at $37^{\circ} \mathrm{C}$ for 5 min and absorbance was measured at $500 \mathrm{~nm}$. The intra- and interassay CV were 3.3 and $5.6 \%$, respectively.

$\boldsymbol{T N F}-\boldsymbol{\alpha} \boldsymbol{A s s a y}$. Spent media were analyzed for concentrations of TNF- $\alpha$ using a bovine-TNF- $\alpha$ commercial kit (VetSet ELISA Development Kit, Kingfisher Biotech Inc., St. Paul, MN) following the manufacturer's protocol. Standards were prepared with $4 \%$ BSA (Sigma-Aldrich Co.) in PBS and samples were diluted to $90 \%$ concentration with the same standard diluent (4\% BSA in PBS). Samples were run in duplicate and all treatments performed in a given cow were run in the same plate. If absorbance was not detected a zero value was assigned. The intra- and interassay CV were 5.4 and $3.1 \%$, respectively.

\section{RNA Isolation, cDNA Synthesis, and qPCR}

Specific details for total RNA isolation and quality evaluation, cDNA synthesis, primer selection and efficiency evaluation, and qPCR analysis are found in Supplemental Material (http://dx.doi.org/10.3168/ jds.2014-9183). Purity of extracted RNA was calculated by absorbance ratio of 260/280 measured using a NanoVue Plus (GE Healthcare, Piscataway, NJ) and averaged 1.85. Integrity of RNA was measured by the RNA quality indicator number (RQI) using an Experion bioanalyzer (Bio-Rad Laboratories Inc.) and averaged 7.4, and neither glucose supplementation nor LPS challenge affected RQI number $(P>0.25)$. Primer sequences and accession number are presented in Supplemental Table S1 (http://dx.doi.org/10.3168/jds.2014-9183). Primer and $\mathrm{qPCR}$ validation detailing the slope, intercept, $\mathrm{R}^{2}$, and efficiency of the dilution curve as well as the range of quantification cycles (Cq) and the median for each gene across all samples are found in Supplemental Table S2 (http://dx.doi.org/10.3168/jds.2014-9183). The $\mathrm{Cq}$ values from target genes were normalized by the geometric mean of 2 ( $R S P 9$ and $O S B P L)$ out of 4 candidate target genes (RSP9, GOLGA5, GAPDH, and $O S B P L$ ) that were previously verified as suitable reference genes in bovine tissue (Janovick-Guretzky et al., 2007; Kadegowda et al., 2009; Moyes et al., 2010). These 2 reference genes were selected based in their lower $\mathrm{M}$ value $(<0.70)$ as recommended by the genorm analysis using the Biogazelle $\mathrm{q}^{+}$software (Biogazelle NV, Zwijnaarde, Belgium) and based on the work of Vandesompele et al. (2002).

The qPCR results, given as $\mathrm{Cq}$ values for each transcript, were analyzed using the $2^{-\Delta \Delta \mathrm{Cq}}$ method (Livak and Schmittgen, 2001). Briefly, the Cq of each target gene was calculated and normalized by the geometric mean of the 2 selected reference genes to generate $\Delta \mathrm{Cq}$ values. The $\Delta \mathrm{Cq}$ values without transformation were subjected to statistical analysis

\section{Statistical Analysis}

The PROC MIXED procedure of SAS (SAS/STAT version 9.2, SAS Institute Inc., Cary, NC) was used for statistical analysis. The data were tested for normality and presence of outliers and were analyzed as a randomized block (stage of lactation) design. For analysis of metabolites in serum and PMNL morphology, the class variables included cow, parity, and stage of lactation (i.e., early and mid-lactation) and the model included the fixed effect of stage of lactation and the random effect of cow nested within parity and stage of lactation. For measure of phagocytosis and chemotaxis (i.e., no LPS), the class variable included cow, parity, glucose, and stage of lactation, and the model included the fixed effects of glucose, stage of lactation, and their interaction and the random effect of cow nested within parity and stage of lactation. For gene expression and medium analyses, data were analyzed using a factorial arrangement $2 \times 2$ with factors including 2 levels of glucose supplementation (i.e., 0.0 and $4 \mathrm{mM}$ ) and 2 doses of LPS (i.e., 0 and $50 \mu \mathrm{g} / \mathrm{mL}$ ). The class variables included cow, parity, glucose, LPS, and stage of lactation. Cow nested within parity and stage of lactation was used as a random term. Separation of LSM and individual comparisons for significant effects were performed using the PDIFF statement in SAS. The model was as follows:

$$
\mathrm{Y}_{\mathrm{ijk}}=\mu+\mathrm{S}_{\mathrm{i}}+\mathrm{G}_{\mathrm{j}}+\mathrm{GS}_{\mathrm{ij}}+\mathrm{L}_{\mathrm{k}}+\mathrm{GL}_{\mathrm{jk}}+\mathrm{SL}_{\mathrm{ik}}+\varepsilon_{\mathrm{ijk}} \text {, }
$$

where $Y_{\mathrm{ijk}}$ is the dependent variable, $\mu$ is overall mean, $S_{i}$ is the fixed effect of stage of lactation $i, G_{j}$ is the fixed effect of glucose level $\mathrm{j}, \mathrm{GS}_{\mathrm{ij}}$ is interaction of glucose $\times$ stage of lactation, $L_{k}$ is the fixed effect of LPS dose $k, G_{\mathrm{jk}}$ is the interaction of glucose $\times$ LPS, $\mathrm{SL}_{\mathrm{ik}}$ is the interaction of stage of lactation $\times$ LPS, and $\varepsilon_{\mathrm{ijk}}$ is the residual error. For all models, the degrees of freedom were estimated with the Kenward-Roger specification in the model statement. The data are presented as LSM and largest SEM. Statistical differences were declared as significant if $P \leq 0.05$ and a trend toward significance if $0.05<P \leq 0.10$. Fold-change values were calculated according to Livak and Schmittgen (2001). Briefly, LSM $(\Delta \mathrm{Cq})$ of a factor of interest was subtracted from the LSM $(\Delta \mathrm{Cq})$ of other referential factor to generate the $\Delta \Delta \mathrm{Cq}$ value, which was linearized to a fold-change value with the formula $2^{-\Delta \Delta \mathrm{Cq}}$. 
Table 1. Serum concentrations of BHBA, NEFA, and glucose and percentage of mature PMNL from Holstein cows in early $(\mathrm{n}=10)$ and mid-lactation $(n=10)$ on the day of neutrophil in vitro challenge

\begin{tabular}{|c|c|c|c|c|}
\hline \multirow[b]{2}{*}{ Metabolite $^{1}$} & \multicolumn{2}{|c|}{ Stage of lactation } & \multirow[b]{2}{*}{ SEM } & \multirow[b]{2}{*}{$P$-value } \\
\hline & Early & Mid & & \\
\hline $\mathrm{BHBA}, \mathrm{mg} / \mathrm{dL}$ & 5.94 & 4.43 & 0.48 & 0.03 \\
\hline NEFA, mEq/L & 0.65 & 0.29 & 0.08 & $<0.01$ \\
\hline Glucose, mg/dL & 57.3 & 59.3 & 2.7 & 0.58 \\
\hline Mature PMNL, \% & 90.7 & 87.3 & 1.4 & 0.12 \\
\hline
\end{tabular}

\section{RESULTS}

\section{Metabolic Status of Cows and Morphology of Their PMNL}

Concentrations of serum BHBA were greater $(P=$ $0.03)$ for cows in early $(5.94 \mathrm{mg} / \mathrm{dL})$ than for cows in mid-lactation $(4.43 \mathrm{mg} / \mathrm{dL}$, Table 1$)$. Similarly, concentrations of serum NEFA were $\sim 2$ times greater $(P<$ $0.01)$ in early than in mid-lactation cows. Serum glucose concentrations did not differ by stage of lactation (57.3 and $59.3 \mathrm{mg} / \mathrm{dL}$ for cows in early and mid-lactation, respectively). No differences $(P=0.12)$ were observed with regard to cell morphology between cows in early $(90.7 \%)$ and mid-lactation (87.3\%).

\section{Gene Expression in PMNL}

Glucose supplementation, LPS challenge, stage of lactation, or their relevant interactions did not affect the expression of genes (SELL, TLR2, TLR4, TLR6; Table 2 ) coding for surface receptors on PMNL. However, the expression of genes involved in the nuclear factor kappa $\mathrm{B}(\mathbf{N F}-\boldsymbol{\kappa} \mathbf{B})$ signaling pathway were moderately altered by glucose where the expression of IRAK1 tended ( $P$ $=0.09)$ to increase in PMNL incubated with GLU compared with CTL (1.12-fold change) but were not altered by LPS challenge, stage of lactation, or their interactions. Expression of NFKB1 in PMNL was not affected by glucose supplementation but increased $(P<$ 0.01) with LPS challenge (1.35-fold change).

Expression of genes coding for pro-inflammatory cytokines was not altered by glucose supplementation but increased $(P<0.01)$ in PMNL challenged with LPS (IL1B, IL6,IL8, and TNFA, fold change: 1.45, $1.96,1.53$, and 1.28 , respectively, Table 2). Stage of lactation affected the expression of $I L 6$, where cows in early lactation tended to have a greater expression when compared with cows in mid-lactation (1.96-fold change). Expression of IL10, gene coding for the antiinflammatory cytokine IL-10 increased $(P \leq 0.03)$ due to LPS challenge (1.30-fold change) and in cows in early compared with cows in mid-lactation (1.61-fold change, $P=0.04)$. With regards to intracellular killing, glucose supplementation increased $(P=0.02)$ the expression of $L Y Z$, coding for the enzyme lysozyme, in PMNL incubated with GLU compared with CTL (1.18fold change). Challenge with LPS decreased $(P=0.03)$ the expression of $L Y Z$ (-1.16-fold change). Expression of SOD2, coding for the enzyme superoxide dismutase 2 , was not affected by either glucose supplementation or LPS challenge but tended to increase in cows in early compared with mid-lactation (1.69-fold change, $P=0.09)$. Genes coding for enzymes (G6PD, LDHA, and PDHA1) and receptors (INSR) involved in glucose metabolism were not altered by glucose, LPS challenge, or stage of lactation or their relevant interactions. The only affected gene involved in glucose metabolism was $S L C 2 A 3$. Challenge with LPS increased $(P=0.01)$ the expression of $S L C 2 A 3$ (1.15-fold change).

The interaction of glucose supplementation $\times$ stage of lactation altered the expression of 3 genes. The expression of NFKB1, encoding NF- $\kappa \mathrm{B}$, in PMNL increased $(P=0.02$, Figure 1A) with glucose supplementation in PMNL from cows in mid- but not from cows in early lactation. The expression of NFKBIA, that codes for NF- $\kappa \mathrm{B}$ inhibitor $\alpha$, tended $(P=0.09$, Figure $1 \mathrm{~B})$ to decrease in PMNL from cows in early compared with cows in mid-lactation incubated with CTL but not with GLU. The expression of IL8 in PMNL incubated with GLU tended ( $P=0.09$, Figure $1 \mathrm{C})$ to increase from cows in mid-lactation but not from cows in early lactation.

The expression of 5 genes was affected by the interaction of LPS $\times$ stage of lactation. Even though the expression of IL 6 increased for all cows after LPS challenge, cows in early lactation tended to have the greatest increase in IL6 expression $(P=0.09$, Figure $2 \mathrm{~A})$. In addition, the expression of $I L 8(P=0.05$, Figure $2 \mathrm{~B})$ and TNFA $(P=0.01$, Figure $2 \mathrm{C})$ increased in LPS-challenged PMNL from cows in early but not from cows in mid-lactation. The expression of $L Y Z$ was influenced by the stage of lactation where cows in midbut not in early lactation tended $(P=0.07$, Figure 2D) to decrease the expression of $L Y Z$ when challenged with LPS. Similarly, LPS-challenged PMNL from cows in early but not from cows in mid-lactation increased the expression of $S L C 2 A 3(P<0.01$, Figure $2 \mathrm{E})$.

\section{Glucose and TNF-a Concentrations in Spent Media}

As expected, the concentration of glucose in the spent media was greater $(P<0.01$, Figure $3 \mathrm{~A})$ in GLU $(145.6$ $\mathrm{mg} / \mathrm{dL})$ when compared with CTL media $(96.7 \mathrm{mg} /$ dL). Challenge of PMNL with LPS increased $(P<0.01)$ the concentrations of TNF- $\alpha$ in spent media (147.3 vs. $72.5 \mathrm{pg} / \mathrm{mL}$, LPS and no LPS challenge, respectively, 
GARCIA ET AL.

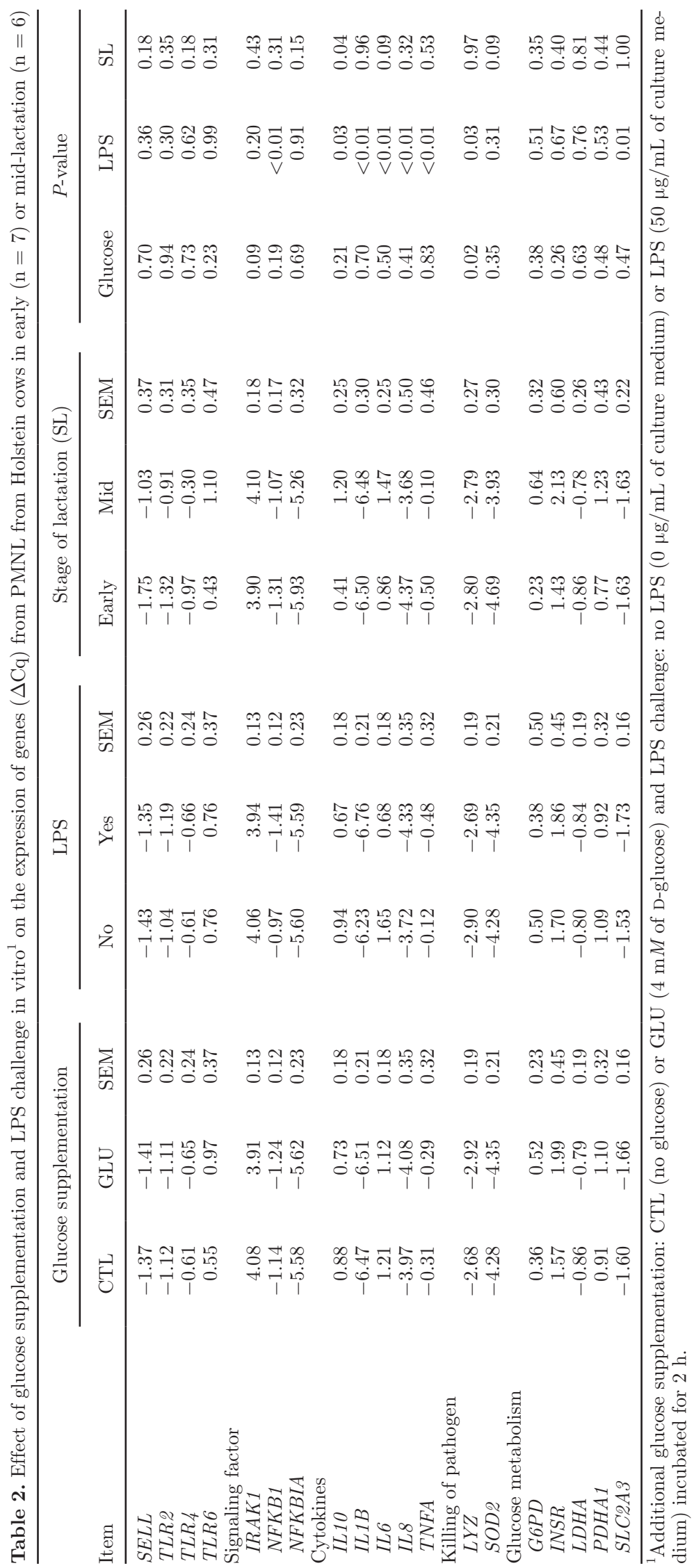




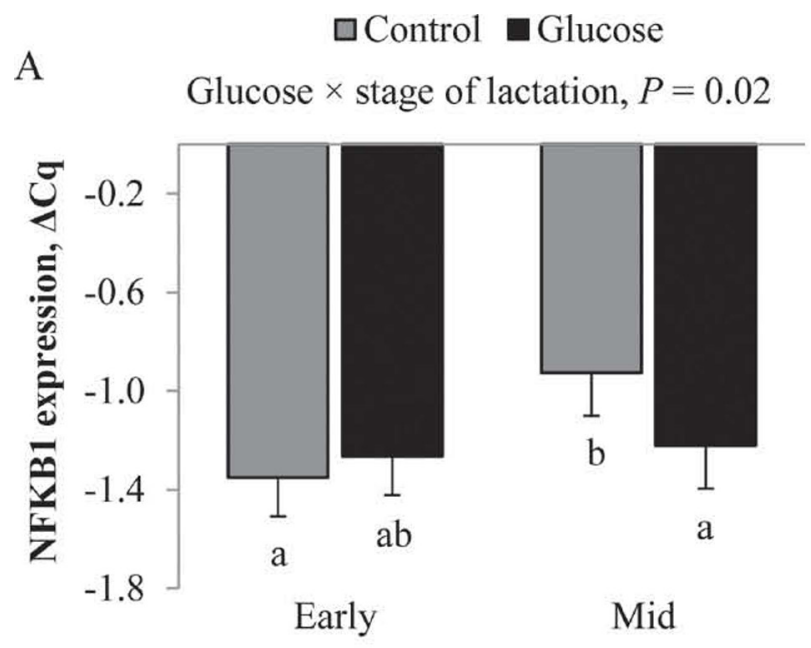

B

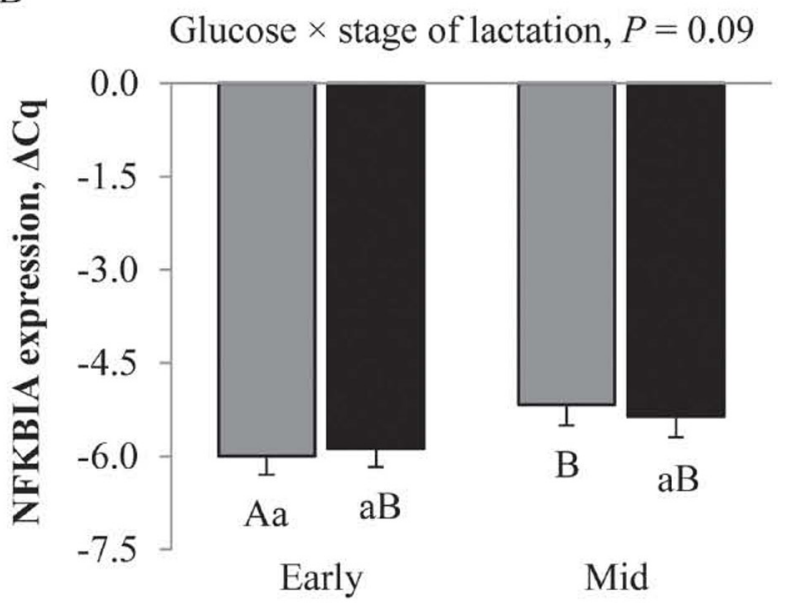

C

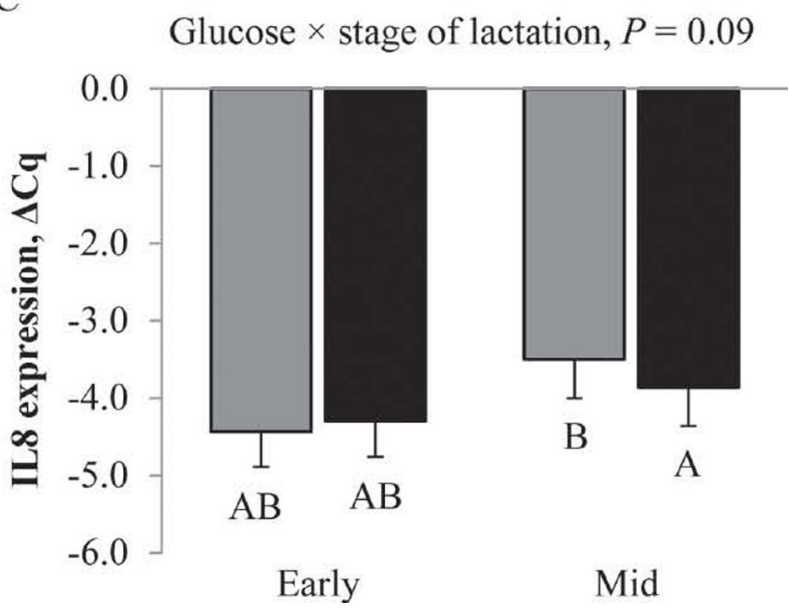

Figure 1. Interaction of glucose supplementation $\times$ stage of lactation on mRNA expression $(\triangle \mathrm{Cq})$ of $N F K B 1(\mathrm{~A}), \operatorname{NFKBIA}(\mathrm{B})$, and $I L 8(\mathrm{C})$ for PMNL from early and mid-lactation cows incubated with $(4 \mathrm{~m} M)$ or without $(0 \mathrm{mM})$ additional glucose and with $(50 \mu \mathrm{g} / \mathrm{mL}$ of culture medium) or without $(0 \mu \mathrm{g} / \mathrm{mL}$ of culture medium) LPS in vitro for $2 \mathrm{~h}$. Means with a different lowercase letter differ $(P \leq 0.05)$, and means with a different uppercase letter tend to differ $(0.05<P$ $\leq 0.10)$.
Figure 3B). Supplementation of glucose increased $(P=$ $0.01)$ the production of TNF- $\alpha$ (135.6 vs. $84.2 \mathrm{pg} / \mathrm{mL}$ for GLU and CTL, respectively, Figure 3C). However, a trend $(P=0.09)$ was observed where glucose supplementation increased production of TNF- $\alpha$ in cows in mid- but not in early lactation (Figure 3C).

\section{Chemotaxis and Phagocytosis by PMNL}

Glucose supplementation did not affect the number of PMNL migrating in response to IL-8 chemoattractant (73 vs. 62 of PMNL for CTL and GLU, respectively, Figure 4A). However, phagocytic function, as measured by engulfment of florescent beads, was improved $(P<$ $0.01)$ with glucose supplementation in vitro. Polymorphonuclear leukocytes incubated with GLU increased their ability to engulf florescent beads by $\sim 11 \%$ compared with PMNL incubated with CTL (Figure 4B).

\section{DISCUSSION}

As expected, cows in early lactation had greater serum BHBA and NEFA than cows in mid-lactation (Bionaz et al., 2007; Qu et al., 2014). Although statistically significant, concentrations of circulating BHBA and NEFA for cows in early lactation were below critical threshold values $(>10 \mathrm{mg} / \mathrm{dL}$ and $>0.6$ to $1.0 \mathrm{mEq} / \mathrm{L}$, respectively) to predict risk of diseases such as displacement of abomasum, metritis, and mastitis, during the first 2 wk of lactation (Jánosi et al., 2003; Ospina et al., 2010; Chapinal et al., 2012). For instance, culture media supplemented with BHBA $(>10 \mathrm{mg} / \mathrm{dL})$ reduced respiratory burst activity of PMNL from healthy cows (Hoeben et al., 1997), and in vivo results are similar where leukocytes from ketotic cows $(49.4 \mathrm{mg} / \mathrm{dL}) \mathrm{had}$ reduced chemotactic capacity when compared with subclinical ketotic $(10.3 \mathrm{mg} / \mathrm{dL})$ cows (Suriyasathaporn et al., 1999). Furthermore, no changes in circulating glucose were observed between cows in early and midlactation for this study. The metabolic profiles may indicate that cows in early lactation were not as metabolically challenged ( $\sim 17$ DIM) as compared with cows around the time of parturition (i.e., when circulating glucose is at a nadir). This supports the minimal effect of glucose supplementation on the expression of genes as well as function of PMNL by stage of lactation.

\section{LPS Induced an Inflammatory Response in PMNL}

In the current study, LPS challenge in vitro increased the expression of several genes coding for inflammatory mediators, as supported by the increased expression of NFKB1, coding for NF- $\kappa \mathrm{B}$, and genes coding for inflammatory cytokines (i.e., IL1B, IL6,IL8,IL10, and 


\section{$\square$ No LPS $\square$ LPS}
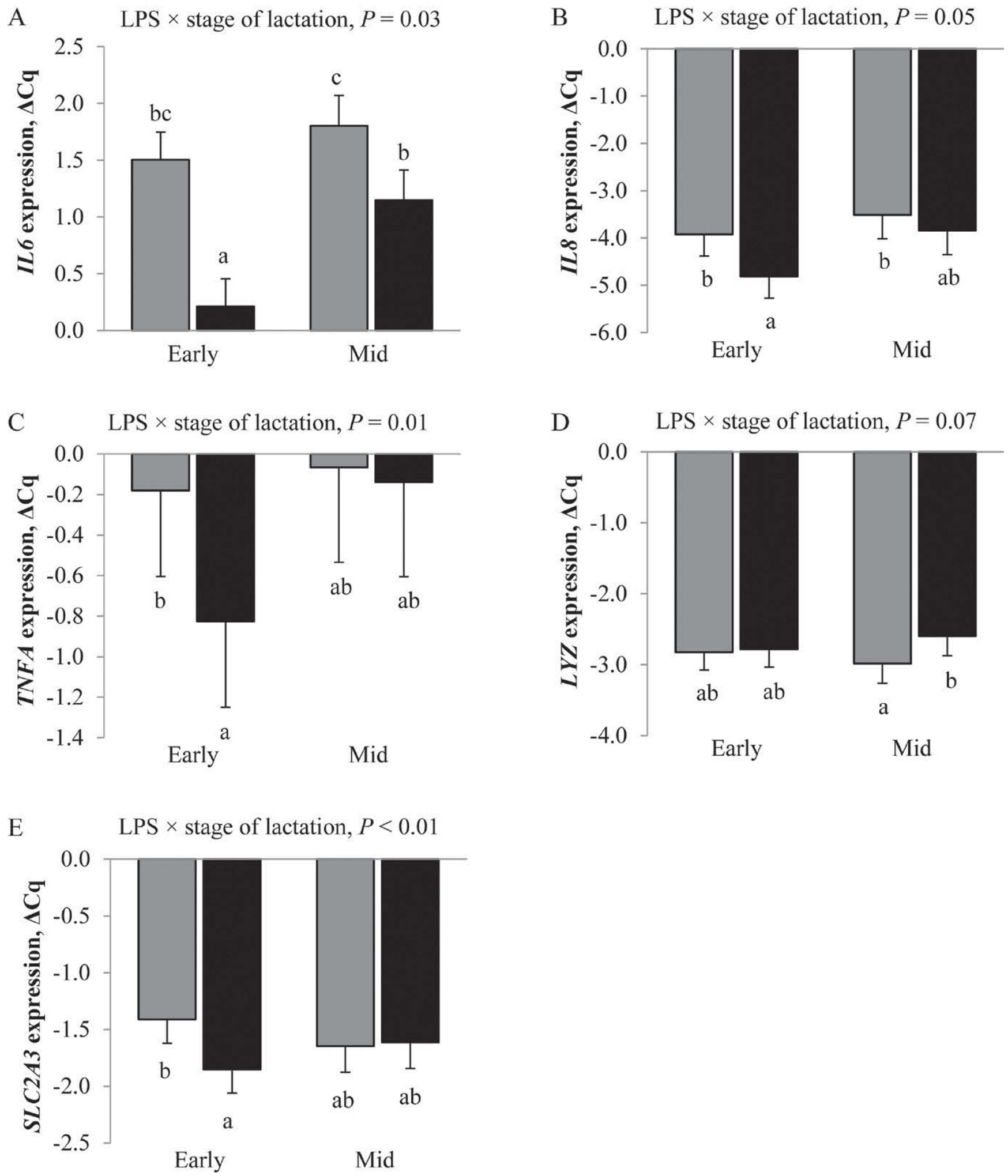

Figure 2. Interaction of LPS challenge $\times$ stage of lactation on mRNA expression ( $\triangle \mathrm{Cq})$ of $I L 6$ (A), IL8 (B), TNFA (C), LYZ (D), and $S L C 2 A 3$ (E) for PMNL from cows in early and mid-lactation incubated with $(4 \mathrm{~m} M)$ or without $(0 \mathrm{~m} M)$ additional glucose and with $(50 \mu \mathrm{g} / \mathrm{mL}$ of culture medium) or without $(0 \mu \mathrm{g} / \mathrm{mL}$ of culture medium) LPS in vitro for $2 \mathrm{~h}$. Means with different letters differ $(P \leq 0.05)$. 
A

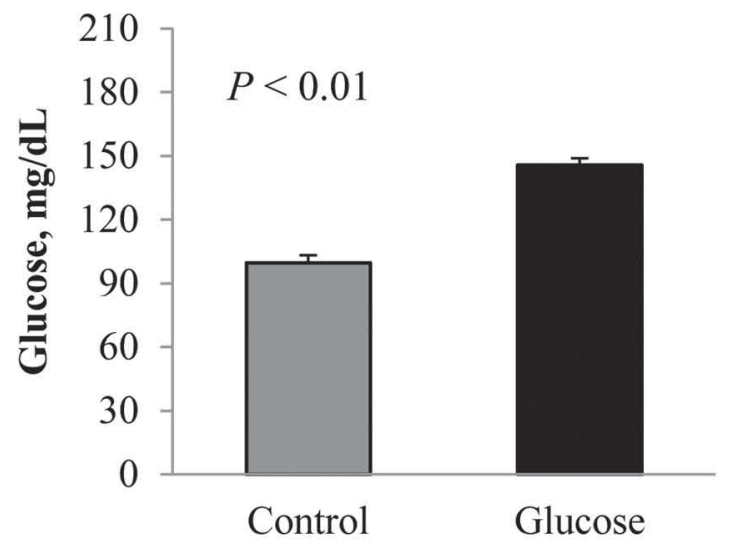

B

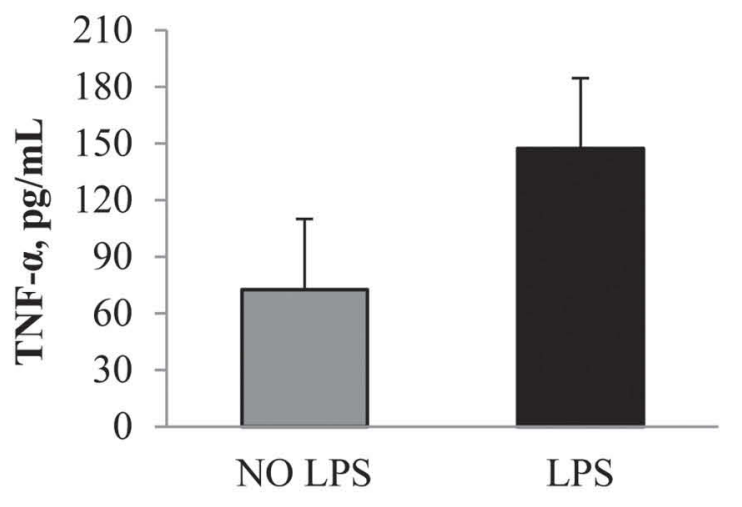

$\mathrm{C}$

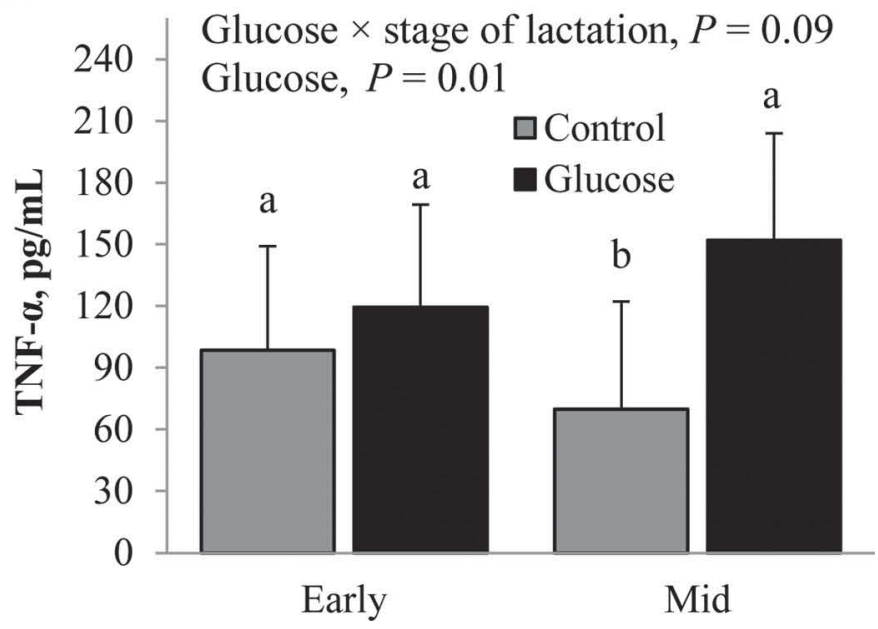

Figure 3. Effect of glucose supplementation (A), LPS challenge (B), and the interaction of glucose supplementation $\times$ stage of lactation (C) on concentrations of glucose and tumor necrosis factor- $\alpha$ $(\mathrm{TNF}-\alpha)$ in spent medium. Polymorphonuclear leukocytes were incubated with $(4 \mathrm{~m} M)$ or without $(0 \mathrm{~m} M)$ additional glucose and with (50 $\mu \mathrm{g} / \mathrm{mL}$ of culture medium) or without $(0 \mu \mathrm{g} / \mathrm{mL}$ of culture medium) LPS in vitro for $2 \mathrm{~h}$. Means with different letters differ $(P \leq 0.05)$.
A

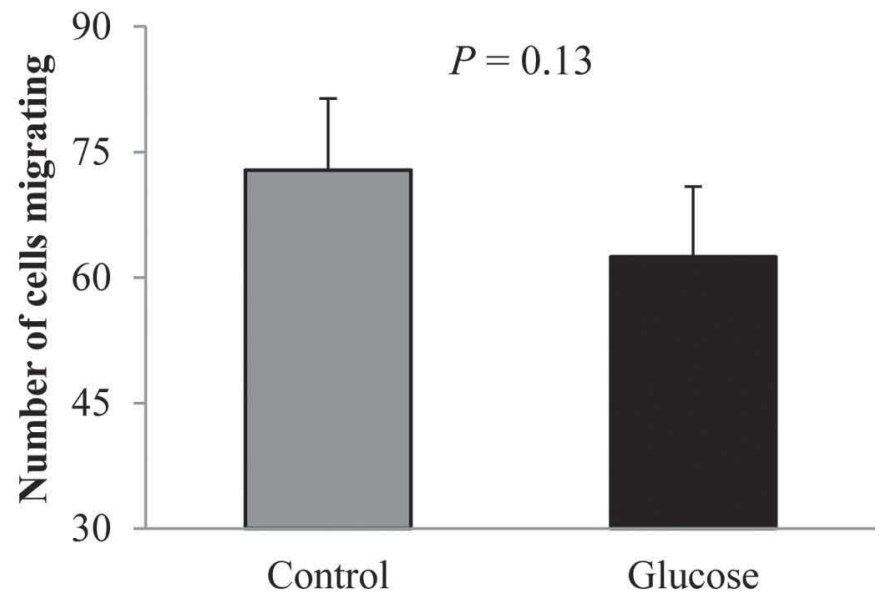

B

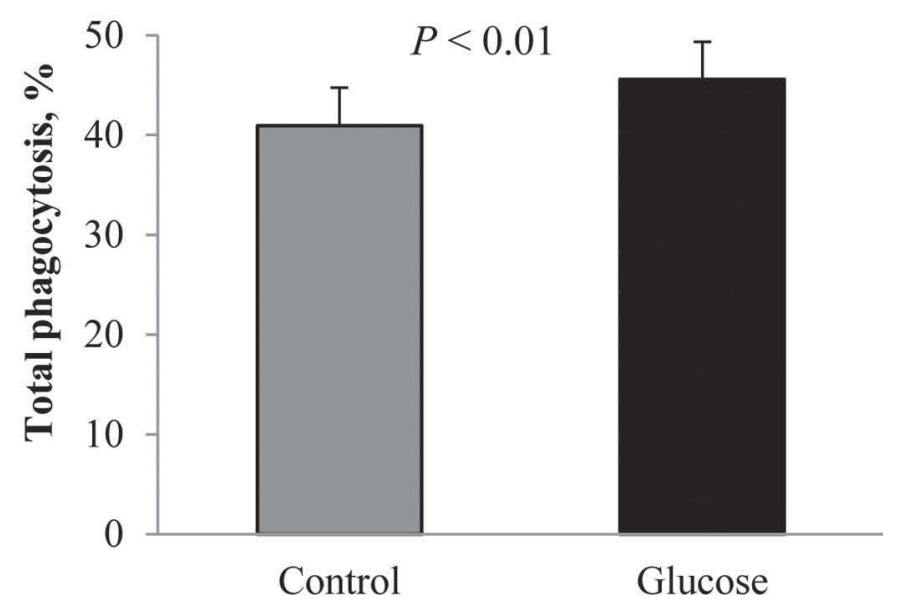

Figure 4. Effect of glucose supplementation on chemotactic response to IL-8 (A) and phagocytic activity (B) of PMNL incubated with $(4 \mathrm{mM})$ or without $(0 \mathrm{mM})$ additional glucose and with $(50 \mu \mathrm{g} /$ $\mathrm{mL}$ of culture medium) or without $(0 \mu \mathrm{g} / \mathrm{mL}$ of culture medium) LPS in vitro for $2 \mathrm{~h}$.

TNFA). The pro-inflammatory response of PMNL to an LPS challenge is further supported by the increased concentrations of TNF- $\alpha$ in the media from PMNL challenged with LPS.

Surprisingly, stage of lactation, as the main effect, did not alter PMNL morphology, chemotaxis, or phagocytosis and may be partly attributed to the lack of marked changes in metabolic profiles as discussed above. Based on gene expression, stage of lactation altered the expression of IL10 and tended to alter that of SOD2 where cows in early lactation had higher expression when compared with cows in mid-lactation. This result may indicate alterations in the anti-inflammatory response at different stages of lactation but warrants fur- 
ther investigation. The interaction of stage of lactation by LPS challenge moderately altered gene expression. Cows in early lactation were observed as having a more marked increase in the expression of genes coding for the pro-inflammatory cytokines $I L 6, I L 8$, and TNFA in response to LPS challenge when compared with cows in mid-lactation. Contradictory to our results, Revelo and Waldron (2012) reported an upregulation of TNFA as well as genes coding for antimicrobial enzymes (BPI and $C Y B A)$ in PMNL from cows in mid-lactation (146 \pm 2 DIM) compared with cows in early lactation (7 DIM) after an intramammary LPS challenge. The differing results regarding gene expression between our experiment and those of Revelo and Waldron (2012) may be associated with the metabolic differences between cows at 7 and 17 DIM as discussed above as well as in vitro versus in vivo LPS challenge models used. However, higher plasma NEFA concentrations indicate increased lipid mobilization for cows in early lactation, and our data support the theory of immune dysfunction, or unregulated inflammatory responses, rather than immunosuppression for cows during early lactation (Sordillo and Raphael, 2013).

Evidence indicates that PMNL are insulin sensitive after LPS challenge, as indicated by an increase in the expression of the insulin-dependent membrane transporter GLUT-4 (Maratou et al., 2007). Although the gene coding for GLUT-4 (i.e., SLC2A4) was not analyzed for this study, the expression of INSR was not altered by LPS challenge, stage of lactation, or by their interaction and may suggest that the protein expression of GLUT-4 may not have been altered. The GLUT-1 receptor, coded by $S L C 2 A 1$, is an insulin-independent receptor responsible for the uptake of glucose into murine PMNL (Schuster et al., 2007). Human studies have revealed that during the inflammatory response, GLUT3 , coded by $S C L C 2 A 3$, is the primary glucose receptor for PMNL rather than GLUT-1 or GLUT-4 (Maratou et al., 2007). Regardless of treatment, the expression of SLC2A1, was minimally expressed $(\mathrm{Cq}>39$, data not shown) for this study, whereas the expression of SLC2A3 was upregulated after LPS challenge and this response was more marked for cows in early than cows in mid-lactation. Gene expression does not necessarily imply synthesis and function of their coded proteins. Neither protein synthesis nor the functional activity of the GLUT-1 and GLUT-3 transporters were measured in the current study. However, the increase of SLC2A3 may signify a potential increase in the translocation of GLUT-3 in response to increased energy demand for PMNL function during inflammation (Simpson et al., 2008). For the current study, neither LPS nor its interaction with stage of lactation altered chemotaxis or phagocytosis in vitro, whereas LPS challenge increased the concentration of TNF- $\alpha$ in media. How the uptake of glucose on PMNL function during inflammation is altered by stage of lactation remains unclear and warrants further investigation.

\section{Glucose Enhances Function of PMNL}

Supplementation of media with glucose upregulated the expression of the pro-inflammatory gene $L Y Z$ and tendency for upregulation of IRAK1, where the latter is part of the signaling cascade leading to the upregulation of NF- $\kappa \mathrm{B}$, indicating that additional glucose may alter the pro-inflammatory response in bovine blood PMNL. Furthermore, the ability of PMNL to engulf one or more of florescent beads, as an indicator of phagocytosis, was greater for PMNL supplemented with glucose when compared with controls. However, supplementation with glucose only resulted in an $11.5 \%$ increase in phagocytosis capabilities in vitro. Coupled with the lack of an effect on PMNL chemotaxis, the biological effect of additional glucose on PMNL function in vivo is uncertain.

Studies using humans and rodent models have reported that glucose utilization (synthesis of lactate and ATP) increased when activated PMNL (Borregaard and Herlin, 1982; Healy et al., 2002) or activated macrophages (Newsholme and Newsholme, 1989; Spolarics et al., 1991) were supplemented with glucose in vitro. Surprisingly, GLU, stage of lactation, and their interaction did not alter the expression of genes coding for proteins involved in glucose uptake (e.g., INSR and $S L C 2 A 3$ ), anaerobic glycolysis (e.g., $L D H A$ ), the citric acid cycle (e.g., PDHA1), the production of ribose and NADPH (e.g., G6PD), and the inflammatory response (e.g., TNFA and IL8). With regard to the inflammatory response, only the expression of NFKB1 and IL8, the latter as a tendency, were altered by the interaction of glucose and stage of lactation where the expression of NFKB1 and IL8 were upregulated for PMNL supplemented with glucose for cows in mid-lactation when compared with cows in early lactation. The increase in expression of NFKB1and IL8 is consistent with the tendency for greater TNF- $\alpha$ concentration in media of PMNL from cows in mid-lactation when supplemented with glucose, whereas no change after glucose supplementation was observed for cows in early lactation. Even though PMNL response to glucose supply was more marked for cows in mid-lactation when compared with cows in early lactation, results may be associated with metabolic status of cows in early lactation when compared with the early postpartum cows as well as differences between in vitro and in vivo situations.

The present experimental model may largely reflect how the body compartmentalizes some of the physi- 
ological compensatory actions needed to preserve specific functions of high importance to survival of the animal (i.e., PMNL activity). As these arise during immune challenge, the necessary regulatory responses are upregulated, driving the reassignments in nutrient priorities when supply is limited (Elsasser et al., 2000, 2006), such as glucose supply for cows in early lactation.

\section{CONCLUSIONS}

Polymorphonuclear leukocytes challenged with LPS resulted in an inflammatory response. An upregulation of SLC2A3 may signify alterations in glucose uptake by PMNL during inflammation, regardless of stage of lactation. Glucose supplementation did not alter the PMNL response to LPS challenge, but the expression of some pro-inflammatory genes was upregulated and phagocytosis was increased after glucose supplementation. These results indicate that glucose supplementation may enhance some aspects of PMNL function throughout lactation. Contrary to our hypothesis, GLU resulted in minimal changes between cows in early and mid-lactation. Glucose supplementation altered the inflammatory response for cows in mid-lactation when compared early lactation and our data indicate that cows in mid-lactation may benefit more from supplemental glucose than cows in early lactation. However, the metabolic profiles measured for cows in early lactation were not representative of cows during the early postpartum period and may partly explain results for this study. Our data are in agreement with the concept that changing metabolic and hormonal environments, normally observed for cows after parturition play a vital role with regard to immunosuppression of blood PMNL normally observed. The biological significance of increased supply of glucose for the immune response during inflammation in vivo remains unclear. Future studies investigating the relationship between glucose supply on PMNL function and whether this is altered by stage of lactation in vivo are warranted.

\section{ACKNOWLEDGMENTS}

This study was funded via the University of Maryland ADVANCE Competitive Grants Program. The authors acknowledge the Agricultural Research Service-USDA staff in Beltsville, Maryland, for their assistance with animal care and data collection. Gratitude is extended to Brian Barrows and undergraduate students Charity Alick and Monica Lincoln, from the University of Maryland, for their laboratory assistance.

\section{REFERENCES}

Barghouthi, S., K. D. Everett, and P. Speert. 1995. Nonopsonic phagocytosis of Pseudomonas aeruginosa requires facilitated transport of D-glucose by macrophages. J. Immunol. 154:3420-3428.

Bionaz, M., E. Trevisi, L. Calamari, F. Librandi, A. Ferrari, and G. Bertoni. 2007. Plasma paraoxonase, health, inflammatory conditions and liver function in transition dairy cows. J. Dairy Sci. 90:1740-1750.

Borregaard, N., and T. Herlin. 1982. Energy metabolism of human neutrophils during phagocytosis. J. Clin. Invest. 70:550-557.

Burvenich, C., D. D. Bannerman, J. Lippolis, L. Peelman, B. Nonnecke, M. Kehrli Jr., and M. Paape. 2007. Cumulative physiological events influence the inflammatory response of the bovine udder to Escherichia coli infections during the transition period. J. Dairy Sci. 90(E. Suppl.):E39-E54.

Chapinal, N., S. J. LeBlanc, M. E. Carson, K. E. Leslie, S. Godden, M. Capel, J. E. P. Santos, M. W. Overton, and T. F. Duffield. 2012. Herd-level association of serum metabolites in the transition period with disease, milk production, and early lactation reproductive performance. J. Dairy Sci. 95:5676-5682.

Drackley, J. K., S. S. Donkin, and C. K. Reynolds. 2006. Major advances in fundamental dairy cattle nutrition. J. Dairy Sci. 89:1324-1336.

Elsasser, T. H., K. L. Ingvartsen, S. Kahl, and A. V. Capuco. 2006. Endocrine effects on immune function: Defining opportunities based on knowledge from growing calf and periparturient animal models. Pages 421-453 in Ruminant Physiology. Digestion, Metabolism and Impact of Nutrition on Gene Expression, Immunology and Stress. K. Sejrsen, T. Hvelplund, and M. O. Nielsen, ed. Wageningen Academic Publishers, Wageningen, the Netherlands.

Elsasser, T. H., K. C. Klasing, N. Filipov, and F. Thompson. 2000. The metabolic consequences of stress: Targets for stress and priorities of nutrient use. Pages 77-110 in The Biology of Animal Stress: Basic Principles and Implications for Animal Welfare. G. Moberg and J. Mench, ed., CABI Publishing, New York, NY.

Furukawa, S., H. Saito, T. Matsuda, T. Inoue, K. Fukatsu, I. Han, S. Ikeda, A. Hidemura, and T. Muto. 2000. Relative effects of glucose and glutamine on reactive oxygen intermediate production by neutrophils. Shock 13:274-278.

Garcia, M., T. Elsasser, D. Biswas, and K. M. Moyes. 2015. The effect of citrus-derived oil on bovine blood neutrophil function and gene expression in vitro. J. Dairy Sci. 98:918-926.

Graugnard, D. E., M. Bionaz, E. Trevisi, K. M. Moyes, J. L. SalakJohnson, R. L. Wallace, J. K. Drackley, G. Bertoni, and J. J. Loor. 2012. Blood immunometabolic indices and polymorphonuclear neutrophil function in peripartum dairy cows are altered by level of dietary energy prepartum. J. Dairy Sci. 95:1749-1758.

Gross, J. J., H. A. Dorland, O. Wellnitz, and R. M. Bruckmaier. 2014. Glucose transport and milk secretion during manipulated plasma insulin and glucose concentrations and during LPS-induced mastitis in dairy cows. J. Anim. Physiol. Anim. Nutr. http://dx.doi. org/10.1111/jpn.12259.

Healy, D. A., R. W. G. Watson, and P. Newsholme. 2002. Glucose, but not glutamine, protects against spontaneous and anti-Fas antibody-induced apoptosis in human neutrophils. Clin. Sci. 103:179-189.

Hoeben, D., R. Heyneman, and C. Burvenich. 1997. Elevated levels of beta-hydroxybutyric acid in periparturient cows and in vitro effect on respiratory burst activity of bovine neutrophils. Vet. Immunol. Immunopathol. 58:165-170.

Ingvartsen, K. L. 2006. Feeding- and management-related disease in the transition cow: Physiological adaptation around calving and strategies to reduce feeding-related diseases. Anim. Feed Sci. Technol. 126:175-213.

Ingvartsen, K. L., and K. Moyes. 2013. Nutrition, immune function and health of dairy cattle. Animal 7:112-122.

Jánosi, S., M. Kulcasár, P. Kóródi, L. Kátai, J. Reiczigel, S. J. Dieleman, J. A. Nikolic, G. Sályi, P. Ribiczey-Szabó, and G. Huszenicza. 2003. Energy imbalance related predisposition to mastitis 
in group-fed high-producing postpartum dairy cows. Acta Vet. Hung. 51:409-424.

Janovick-Guretzky, N. A., H. M. Dann, D. B. Carlson, M. R. Murphy, J. J. Loor, and J. K. Drackley. 2007. Housekeeping gene expression in bovine liver is affected by physiological state, feed intake, and dietary treatment. J. Dairy Sci. 90:2246-2252.

Kadegowda, A. K. G., M. Bionaz, B. Thering, L. S. Piperova, R. A Erdman, and J. J. Loor. 2009. Identification of internal control genes for quantitative polymerase chain reaction in mammary tissue of lactating cows receiving lipid supplements. J. Dairy Sci. 92:2007-2019.

Kehrli, M. E. Jr., and D. E. Shuster. 1994. Factors affecting milk somatic cells and their role in health of the bovine mammary gland. J. Dairy Sci. 77:619-627.

Livak, K. J., and T. D. Schmittgen. 2001. Analysis of relative gene expression data using real-time quantitative PCR and the 2(-delta delta $\mathrm{C}(\mathrm{T})$ ) method. Methods 25:402-408.

Maratou, E., G. Dimitriadis, A. Kollias, E. Boutati, V. Lambadiari, P. Mitrou, and S. A. Raptis. 2007. Glucose transporter expression on the plasma membrane of resting and activated white blood cells. Eur. J. Clin. Invest. 37:282-290.

Moyes, K. M., J. K. Drackley, D. E. Morin, and J. J. Loor. 2010 Greater expression of TLR2, TLR4, and IL6 due to negative energy balance is associated with lower expression of HLA-DRA and HLA-A in bovine blood neutrophils after intramammary mastitis challenge with Streptococcus uberis. Funct. Integr. Genomics 10:53-61.

Moyes, K. M., J. K. Drackley, J. L. Salak-Johnson, D. E. Morin, J. C. Hope, and J. J. Loor. 2009. Dietary-induced negative energy balance has minimal effects on innate immunity during a Streptococcus uberis mastitis challenge in dairy cows during midlactation. J. Dairy Sci. 92:4301-4316.

Moyes, K. M., T. Larsen, P. Sorensen, and K. L. Ingvarsten. 2014 Metabolic responses in blood and milk during experimental Escherichia coli mastitis for primiparous Holstein dairy cows during early lactation. J. Anim. Sci. Biotechnol. 5:47-57.

Newsholme, P., S. Gordon, and E. A. Newsholme. 1987. Rates of utilization and fates of glucose, glutamine, pyruvate, fatty acids and ketone bodies by mouse macrophages. Biochem. J. 242:631-636.

Newsholme, P., and E. A. Newsholme. 1989. Rates of utilization of glucose, glutamine and oleate and formation of end-products by mouse peritoneal macrophages in culture. Biochem. J. 261:211218.

NRC. 2001. Nutrient Requirements of Dairy Cattle. 7th rev. ed. Natl. Acad. Sci., Washington, DC.

Ospina, P. A., D. V. Nydam, T. Stokol, and T. R. Overton. 2010. Evaluation of nonesterified fatty acids and $\beta$-hydroxybutyrate in transition dairy cattle in the northeastern United States: Thresholds for prediction of clinical diseases. J. Dairy Sci. 93:546-554.

Paape, M. J., D. D. Bannerman, X. Zhao, and J. W. Lee. 2003. The bovine neutrophil: Structure and function in blood and milk. Vet. Res. 34:597-627.

Pithon-Curi, T. C., M. P. De Melo, and R. Curi. 2004. Glucose and glutamine utilization by rat lymphocytes, monocytes and neutrophils in culture: A comparative study. Cell Biochem. Funct. 22:321-326.

Qu, Y., A. N. Fadden, M. G. Traber, and G. Bobe. 2014. Potential risk indicators of retained placenta and other diseases in multiparous cows. J. Dairy Sci. 97:4151-4165.

Revelo, X. S., and M. R. Waldron. 2012. In vitro effects of Escherichia coli lipopolysaccharide on the function and gene expression of neutrophils isolated from the blood of dairy cows. J. Dairy Sci 95:2422-2441.

Schuster, D. P., S. L. Brody, Z. Zhou, M. Bernstein, R. Arch, D. Link and M. Mueckler. 2007. Regulation of lipopolysaccharide-induced increases in neutrophil glucose uptake. Am. J. Physiol. Lung Cell. Mol. Physiol. 292:L845-L851.

Simpson, I. A., D. Dwyer, D. Malide, K. H. Moley, A. Travis, and S. J. Vannucci. 2008. The facilitative glucose transporter GLUT3: 20 years of distinction. Am. J. Physiol. Endocrinol. Metab. 295:E242-E253.

Sordillo, L. M., and W. Raphael. 2013. Significance of metabolic stress, lipid mobilization, and inflammation on transition cow disorders Vet. Clin. North Am. Food Anim. Pract. 29:267-278.

Spolarics, Z., C. H. Lang, G. J. Bagby, and J. J. Spitzer. 1991. Glutamine and fatty acid oxidation are the main sources of energy in Kupffer and endothelial cells. Am. J. Physiol. 261:G185-G190.

Steiger, M., M. Senn, G. Altreuther, D. Werling, F. Sutter, M. Kreuzer, and W. Langhans. 1999. Effect of a prolonged low-dose lipopolysaccharide infusion on feed intake and metabolism in heifers. J. Anim. Sci. 77:2523-2532.

Ster, C., M. C. Loiselle, and P. Lacasse. 2012. Effect of postcalving serum nonesterified fatty acids concentration on the functionality of bovine immune cells. J. Dairy Sci. 95:708-717.

Suriyasathaporn, W., A. J. Daemen, E. N. Noordhuizen-Stassen, S. J. Dieleman, M. Nielen, and Y. H. Schukken. 1999. Betahydroxybutyrate levels in peripheral blood and ketone bodies supplemented in culture media affect the in vitro chemotaxis of bovine leukocytes. Vet. Immunol. Immunopathol. 68:177-186.

Vandesompele, J., P. K. De, F. Pattyn, B. Poppe, R. N. Van, P. A. De, and F. Speleman. 2002. Accurate normalization of real-time quantitative RT-PCR data by geometric averaging of multiple internal control genes. Genome Biol. 3:RESEARCH0034. 